\title{
PENGARUH TOTAL AKTIVA, CAPITAL ADEQUACY RATIO (CAR), FINANCE TO DEPOSIT RATIO (FDR) DAN NON PERFORMING FINANCING (NPF) TERHADAP RETURN ON ASSETS (ROA) BANK UMUM SYARIAH DI INDONESIA PERIODE 2010-2014'
}

\author{
Okyviandi Putra Erlangga \\ Program Studi S1 Ekonomi Islam-Fakultas Ekonomi dan Bisnis-Universitas Airlangga \\ Email: okyviandiputra@gmail.com \\ Imron Mawardi \\ Departemen Ekonomi Syariah-Fakultas Ekonomi dan Bisnis-Universitas Airlangga \\ Email: ronmawardi@yahoo.co.id
}

\begin{abstract}
:
The purpose of this study is to analyze the impact of the variables firm size, liquidity, capital adequacy and financing fraud on Sharia Bank profitability in Indonesia by January 2010 until December 2014 period. Research using purposive sampling method for taking samples. Data obtained based on Bank of Indonesia published via Website realtime, obtained 60 samples.

Research variables consisted of four independent variables and 1 dependent variable. Data analysing technique to answer research problem and examine research hypothesis using Double Linear Regression Analysis that supported by SPSS Statistics version 20 application.

Based on the research, known that the effect of firm size (asset total), Liquidity (FDR), financing fraud (NPF) on Sharia Bank profitability partially significant. Meanwhile, the effect of capital adequacy (CAR) on Sharia Bank profitability not too significant
\end{abstract}

Keywords : Sharia Bank, Profitability, Financing Fraud, Asset Total

\section{PENDAHULUAN}

Islam merupakan agama yang sempurna dan telah mengatur segala aspek kegiatan manusia secara menyeluruh, mulai dari hubungan pribadi dengan Allah SWT yang diatur melalui hubungan ibadah, hingga hubungan pribadi dengan pribadi lainnya, pribadi dengan lingkungannya bahkan pribadi dengan dirinya sendiri yang diatur dalam hubungan muamalah

Bank merupakan lembaga perantara keuangan (financial intermediaries) yang menyalurkan dana dari pihak yang memiliki dana lebih (surplus unit) kepada pihak yang memiliki dana kurang (deficit unit) pada waktu yang ditentukan (Dendawijaya, 2009: 14). Bank mempunyai fungsi sebagai penghimpun dan penyalur

dana masyarakat, bank mendasarkan kegiatan usahanya pada kepercayaan masyarakat (agent of trust). Selain sebagai agent of trust bank juga berfungsi bagi pembangunan nasional dalam rangka meningkatkan pemerataann, pertumbuhan ekonomi, dan stabilitas ekonomi (Hasibuan, 2005: 4).

Undang-undang no. 10 Tahun 1998 tentang Perbankan, mendefinisikan Bank sebagai badan usaha yang menghimpun dana dari masyarakat dalam bentuk simpanan dan menyalurkan pada masyarakat dalam bentuk kredit dan atau bentuk- bentuk lainnya dalam rangka meningkatkan taraf hidup rakyat banyak. Berdasarkan pasal 5 undang undang no. 10 Tahun 1998 tentang Perbankan,

1) Jurnal ini merupakan bagian dari skripsi yang ditulis oleh (Okyviandi Putra Erlangga; 041 114004 ) yang diuji pada 10 Agustus 2015 
Erlangga, et al/Jurnal Ekonomi Syariah Teori dan Terapan Vol. 3 No. 7 Juli 2016: 561-574; PENGARUH TOTAL AKTIVA, CAPITAL ADEQUACY RATIO (CAR), FINANCE TO DEPOSIT RATIO (FDR) DAN NON PERFORMING FINANCING (NPF) TERHADAP RETURN ON ASSETS (ROA) BANK UMUM SYARIAH DI INDONESIA PERIODE 2010-2014

terdapat dua jenis bank yaitu Bank Umum dan Bank Perkreditan Rakyat. Kedua jenis bank tersebut dalam menjalankan kegiatan usahanya diklasifikasikan dalam menjadi dua yaitu Konvensional dan bank dengan menggunakan prinsip syariah.

Bank Syariah awalnya dikembangkan sebagai suatu respon yang sangat positif dari kelompok Ekonom Muslim dan praktisi perbankan Muslim serta para ulama yang berusaha mengakomodasi desakan dari berbagai pihak yang menginginkan agar tersedia jasa transaksi kevangan yang mirip dengan Bank Konvensional namun dilaksanakan sejalan dengan nilai-nilai dan prinsip-prinsip Syariah dalam Islam. Secara Filosofis Bank Syariah merupakan Bank yang segala aktifitasnya meninggalkan hal yang berkaitan dengan masalah riba. Penghindaran bunga yang notabene sama dengan dengan Riba berdasarkan fatwa Majelis Ulama Indonesia (MUI) nomor 1 tahun 2004 merupakan tantangan terbesar yang dihadapi Bank Syariah. Sebagaimana dijelaskan secara jelas pada Al-Qurán Surat Ali Imron ayat 130:

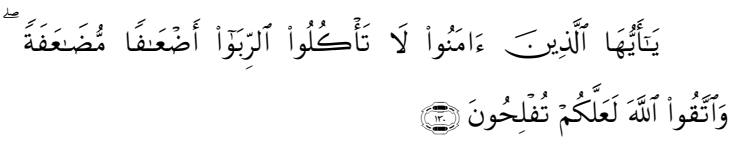

Yaa ayyuhallazina amanu la ta'kulur-riba ad'a fam muda'afataw wattaqullaha la'allakum tuflihun

Artinya: "Hai orang-orang yang beriman, janganlah kamu memakan Riba dengan berlipat ganda dan bertakwalah kamu kepada Allah supaya kamu mendapat keberuntungan."

ayat diatas menjelaskan kepada kita betapa haram dan buruknya riba dan melarang mengambil harta Riba dan orang-orang yang mengambil harta riba dijelaskan oleh Allah SWT seorang yang mengambil harta riba merupakan penghuni neraka yang kekal.

Perkembangan di dunia perbankan syariah yang sangat pesat serta kompleksitas yang tinggi, dapat mempengaruhi performa suatu bank. Kompleksitas perbankan syariah yang tinggi dapat meningkatkan resiko yang dihadapi oleh bank-bank syariah yang ada di Indonesia. Lemahnya kondisi bank syariah seperti manajemen yang kurang memadai, pemberian kredit kepada kelompok atau grup usaha sendiri serta modal yang tidak dapat menutupi resikoresiko yang dihadapi bank menyebabkan kinerja bank syariah tersebut menurun. Akhirnya, ketika kinerja bank syariah menurun maka kepercayaan masyarakat terhadap bank juga akan menurun dan profitabilitas bank pun akan ikut berpengaruh seperti menurunnya keuntungan bank atas kegiatan usahanya.

Faktor-faktor yang dapat mempengaruhi profitabilitas bank dalam hal ini Return On Assets bersumber dari berbagai kinerja operasi yang ditunjukan beberapa indikator. Salah satu sumber utama indikator yang dijadikan dasar penelitian adalah laporan keuangan bank periodik yang berisi beberapa rasio-rasio kevangan seperti yang digunakan dalam penelitian ini diantaranya Capital Adequacy Ratio (CAR), Financing to Deposit Ratio (FDR), Non Performing 
Erlangga, et al/Jurnal Ekonomi Syariah Teori dan Terapan Vol. 3 No. 7 Juli 2016: 561-574; PENGARUH TOTAL AKTIVA, CAPITAL ADEQUACY RATIO (CAR), FINANCE TO DEPOSIT RATIO (FDR) DAN NON PERFORMING FINANCING (NPF) TERHADAP RETURN ON ASSETS (ROA) BANK UMUM SYARIAH DI INDONESIA PERIODE 2010-2014

Financing (NPF) dan Total Aktiva atau Total Asset.

Tabel 1.

Rasio Perbankan Syariah Indonesia

\begin{tabular}{|l|c|c|c|c|c|}
\hline Indikato & 201 & 201 & 201 & 201 & 201 \\
r & 0 & 1 & 2 & 3 & 4 \\
\hline ROA & 1,67 & 1,79 & 2,14 & 2,00 & 0,85 \\
\hline CAR & 16,2 & 16,6 & 14,1 & 14,1 & 15,7 \\
\hline FDR & 89,6 & 88,9 & 100 & 102 & 91,5 \\
\hline BOPO & 80,5 & 78,4 & 74,9 & 77,9 & 94,1 \\
\hline NPF & 3,02 & 2,52 & 2,2 & 2,87 & 4,33 \\
\hline
\end{tabular}

Tahun 2010-2014

Sumber : www.bi.go.id, diolah (2015)

Tabel 1 diatas menjelaskan bahwa secara empirik tampak bahwa rasio-rasio keuangan dari tahun ke tahun mengalami perubahan. Selain itu terdapat penyimpangan dengan teori yang menyatakan hubungan CAR, FDR, dan NPF terhadap ROA.

Pada tahun 2012 ketika ROA naik menjadi 2,14\%, CAR justru mengalami penurunan sebesar 2,50\%. Namun, sebaliknya ketika ROA turun pada tahun 2013 dan 2014 masing-masing sebesar $2,00 \%$ dan $0,85 \%$, CAR justru mengalami kenaikan sebesar 14,17\% pada tahun 2013 dan $15,74 \%$ pada tahun 2014. Hal ini bersimpangan dengan teori yang menyatakan bahwa CAR berhubungan positif dengan ROA.

Rasio FDR juga mengalami penyimpangan dengan teori yang ada. Saat rasio FDR turun sebesar $0,73 \%$ pada tahun 2011, ROA justru mengalami kenaikan sebesar $0,12 \%$. Namun sebaliknya, ketika rasio FDR naik sebesar 2,76\% pada tahun 2013, ROA justru mengalami penurunan sebesar $0,14 \%$ sehingga menimbulkan kesan bahwa FDR berpengaruh negatif terhadap ROA. Namun, teori mengatakan bahwa FDR berpengaruh positif terhadap ROA.

Dari fenomena gap di atas, dapat ditarik kesimpulan bahwa tidak setiap kejadian empiris sesuai dengan teori yang ada. Hal tersebut diperkuat adanya research gap dalam penelitian-penelitian terdahulu yang mempunyai perbedaan hasil antar penelitian meskipun variabel yang diteliti sama.

Berdasarkan uraian diatas maka rumusan masalah yang ingin diajukan dalam penelitian ini adalah Apakah Total Aktiva, Capital Adequacy Ratio (CAR), Finance to Deposit Rasio (FDR) dan Non Performing Financing (NPF) berpengaruh terhadap Return on Asset (ROA) Bank Syariah di Indonesia secara simultan dan secara parsial?

Adapun tujuan yang ingin dicapai dari penelitian ini adalah Untuk mengetahui pengaruh Total Aktiva, , Capital Adequacy Ratio (CAR), Finance to Deposit Rasio (FDR) dan Non Performing Financing (NPF) berpengaruh terhadap Return on Asset (ROA) Bank Syariah di Indonesia secara simultan maupun secara parsial.

\section{TINJAUAN PUSTAKA \\ Bank Syariah}

Menurut Undang-Undang No. 7 Tahun 1992 tentang perbankan sebagaimana telah diubah dengan Undang-Undang RI No. 10 Tahun 1998 tentang perbankan mendefinisikan bank sebagai badan 
Erlangga, et al/Jurnal Ekonomi Syariah Teori dan Terapan Vol. 3 No. 7 Juli 2016: 561-574; PENGARUH TOTAL AKTIVA, CAPITAL ADEQUACY RATIO (CAR), FINANCE TO DEPOSIT RATIO (FDR) DAN NON PERFORMING FINANCING (NPF) TERHADAP RETURN ON ASSETS (ROA) BANK UMUM SYARIAH DI INDONESIA PERIODE 2010-2014

usaha yang menghimpun dana dari masyarakat dalam bentuk simpanan dan menyalurkan kepada masyarakat dalam rangka meningkatkan taraf hidup rakyat banyak. Bank dalam menjalankan usahanya menghimpun dana dari masyarakat dan menyalurkannya kembali dalam berbagai alternatif investasi. Oleh karena itu, bank sering pula disebut lembaga kepercayaan.

Undang-Undang No.10 Tahun 1998, pasal 1 (13) tentang Perbankan, yang menyebutkan bahwa:

"Prinsip syariah adalah sebagai aturan perjanjian berdasarkan hukum syariah antara bank dengan pihak lain untuk penyimpanan dana dan pembiayaan kegiatan usaha atau kegiatan lainnya yang dinyatakan sesuai dengan syariah antara lain : pembiayaan berdasarkan prinsip bagi hasil (mudharabah), pembiayaan berdasarkan berdasarkan prinsip penyertaan modal (musyarakah), pembiayaan berdasarkan prinsip jual beli barang dengan memperoleh keuntungan (murabahah), atau pembiayan barang modal berdasarkan prinsip sewa murni tanpa pilihan (ijarah), atau dengan adanya pilihan pemindahan kepemilikan atas barang yang disewa dari pihak bank oleh pihak lain (ijarah wal istisna)."

Laporan keuangan merupakan suatu intisari dari transaksi-transaksi yang telah dilakukan selama tahun buku yang bersangkutan. Secara umum, tujuan utama dari pembuatan laporan kevangan adalah memberikan informasi yang berguna bagi pemakai laporan keuangan untuk pengambilan keputusan ekonomis tahun berikutnya. (Tondowidjojo dan Purwaningsih, 2007 : 54). Laporan keuangan bank menunjukkan kondisi keuangan bank secara keseluruhan. Berdasarkan laporan keuangan tersebut akan terlihat bagaimana kondisi riil bank sesungguhnya, termasuk kelemahan dan kekuatan yang dimiliki oleh bank. Analisis laporan kevangan adalah suatu analisis yang terdiri atas berbagai jenis teknik yang digunakan oleh seluruh pengguna laporan keuangan untuk mengetahui hubungan-hubungan dalam laporan keuangan yang akhirnya untuk menentukan keputusan yang diambil di tahun mendatang.

kinerja (performance) bank adalah gambaran mengenai prestasi kerja perusahaan bank atau kemampuan kerja perusahaan bank atas kegiatan operasional yang dilakukan.

Chiang et al. (2009), menyatakan bahwa perusahaan yang memiliki keuntungan tinggi dapat membiayai pertumbuhannya menggunakan laba ditahan sembari mepertahankan rasio hutang pada tingkatan yang konstan. Sementara itu, perusahaan yang memiliki keuntungan kecil dipaksa untuk menggunakan pembiayaan hutang. Penelitian ini menggunakan Return on Assets (ROA) sebagai proksi pengukur profitablitas.

Berikut ini rumus dalam mencari Return on Asset (ROA) :

$$
\text { ROA }=\frac{E A T}{\text { TotalAssets }} \times 100 \%
$$

Ukuran Perusahaan adalah suatu skala, yaitu dapat diklasifikasikan besar kecilnya perusahaan melalui berbagai 
Erlangga, et al/Jurnal Ekonomi Syariah Teori dan Terapan Vol. 3 No. 7 Juli 2016: 561-574; PENGARUH TOTAL AKTIVA, CAPITAL ADEQUACY RATIO (CAR), FINANCE TO DEPOSIT RATIO (FDR) DAN NON PERFORMING FINANCING (NPF) TERHADAP RETURN ON ASSETS (ROA) BANK UMUM SYARIAH DI INDONESIA PERIODE 2010-2014

cara, antara lain total aktiva, log size, nilai pasar saham, dan stabilitas penjualan.

Total aktiva dipilih sebagai proksi ukuran perusahaan dengan mempertimbangkan bahwa nilai aktiva atau asset relatif lebih stabil dibandingkan dengan nilai kapitalisasi pasar dan penjualan (Wuryatiningsih, 2002) serta proksi-proksi lainnya.

Likuiditas dapat didefinisikan sebagai kemampuan untuk memenuhi kebutuhan dana (cashflow) dengan segera dan dengan biaya yang sesuai.

Proksi yang digunakan dalam penelitian ini dalam menghitung likuiditas bank syariah adalah Financing to Deposit Ratio (FDR) yaitu seberapa besar dana bank syariah dilepaskan untuk pembiayaan. Ketentuan Bank Indonesia tentang FDR yaitu antara rasio $80 \%$ hingga $110 \%$ FDR merupakan rasio yang mengukur kemampuan bank untuk memenuhi kewajiban keuangan yang harus dipenuhi.

Berikut rumus dalam mencari FDR :

$$
F D R=\frac{\text { TotalPembiayaan }}{\text { TotalDanaPihakKetiga }} \times 100 \%
$$

kecukupan modal merupakan penilaian terhadap kecukupan modal bank untuk mengantisipasi risiko yang akan dihadapi Modal merupakan aspek penting bagi suatu unit bisnis bank. Hal itu dikarenakan beroperasi atau tidaknya dan dipercaya atau tidaknya suatu bank salah satunya dipengaruhi oleh kondisi kecukupan modal.
Rasio untuk mengukur kecukupan modal bank syariah yaitu dengan menggunakan rasio Capital Adequacy Ratio. Berdasarkan ketentuan Bank for International Settlements, bank yang dinyatakan termasuk sebagai bank yang sehat harus memiliki CAR paling sedikit sebesar $8 \%$ permodalan terhadap aktiva berisiko (Muhammad, 2005: 249).

Berikut rumus dalam mencari CAR :

$$
\begin{aligned}
& \text { CAR }=\frac{\text { ModalSendiri }}{\text { ATMR }} \times 100 \% \\
& \text { Setiap }
\end{aligned}
$$

dana bank dalam aktiva produktif bank syariah dinilai kualitasnya berdasarkan pendekatan jaminan, pendekatan karakter, kemampuan pelunasan, kelayakan usaha, dan pendekatan fungsi bank sebagai lembaga perantara keuangan (Muhammad, 2005 :305). Penilaian Kualitas Aktiva Produktif dilakukan dengan menentukan tingkat kolektibilitasnya. Kolektibilitas merupakan tingkat kelancaran pembayaran kewajiban nasabah yang berdasarkan jumlah hari tunggakan. Kolektibilitas selain berpengaruh pada tingkat kesehatan bank syariah juga berpengaruh pada perolehan laba bank. Secara umum kolektibilitas pembiayaan dikategorikan menjasi 5 (Muhammad 2005 : 312) macam, yaitu lancar, kurang lancar, diragukan, perhatian khusus, dan macet.

Adanya pembiayaan bermasalah yang semakin besar dibandingkan aktiva produktif, bank dapat kehilangan 
Erlangga, et al/Jurnal Ekonomi Syariah Teori dan Terapan Vol. 3 No. 7 Juli 2016: 561-574; PENGARUH TOTAL AKTIVA, CAPITAL ADEQUACY RATIO (CAR), FINANCE TO DEPOSIT RATIO (FDR) DAN NON PERFORMING FINANCING (NPF) TERHADAP RETURN ON ASSETS (ROA) BANK UMUM SYARIAH DI INDONESIA PERIODE 2010-2014

kesempatan untuk memperoleh pendapatan dari pembiayaan yang diberikan sehingga mempengaruhi perolehan laba dan berpengaruh buruk pada ROA (Dendawijaya,2009: 82).

Pembiayaan Bermasalah pada bank syariah dapat diukur dengan Non Performing Financing (NPF) (Muhammad, 2005). NPF digunakan untuk mengukur tingkat permasalahan pembiayaan yang dihadapi oleh bank syariah. NPF itu sendiri mencerminkan risiko pembiayaan yang dihadapi oleh bank syariah. Semakin tinggi rasio ini, menunjukkan kualitas pembiayaan bank syariah semakin buruk.

Berikut rumus dalam mencari NPF

$N P F=\frac{\text { TotalPembiayaanBermasalah }(K L, D, M)}{\text { TotalPembiayaan }} \times 100 \%$

Sehingga berdasarkan penjabaran diatas dapat diambil hipotesis bahwa terdapat pengaruh Total aktiva, Capital Adequacy Ratio (CAR), Financing to Deposit Ratio (FDR) dan Non Performing Financing (NPF) terhadap Return on Assets (ROA) pada Bank Syariah secara simultan maupun secara parsial.

\section{METODE PENELITIAN}

\section{Pendekatan Penelitan}

Penelitian ini menggunakan pendekatan kuantitatif untuk menjawab rumusan masalah. Pendekatan kuantitatif ini menitikberatkan pada pengujian hipotesis, menggunakan data-data yang terukur dan alat analisis statistik inferensial parametrik dimana statistik inferensial parametrik setelah data dikumpulkan maka dilakukakan berbagai metode statistik untuk menganalisa data dna kemudian menginterpretasikan hasil analisa tersebut dengan memakai skala rasio. (Sugiyono, 2004)

\section{Identifikasi Variabel}

Berdasarkan model analisis dan hipotesis, maka dapat diidentifikasi bahwa Return on Asset (ROA) merupakan variabel dependen / terikat sedangkan Total Aktiva, Capital Adequacy Ratio (CAR), Financing to Deposit Ratio (FDR) dan Non Performing Financing (NPF) adalah sebagai variabel independen / bebas.

\section{Jenis dan Sumber Data}

Penelitian ini menggunakan data sekunder yang berupa rasio keuangan pada bank syariah. Data yang digunakan dalam penelitian ini merupakan data sekunder yang diambil dari Statistik Perbankan Syariah. Data tersebut diterbitkan oleh website resmi Otoritas Jasa Keuangan (OJK) dan Bank Indonesia (BI).

\section{Sampel}

Sampel dalam penelitian diambil secara sengaja (Purposive Sampling) dengan tujuan untuk melakukan penelitian pada industri bank syariah yang diambil dari data Bank Umum Syariah (BUS) dan Unit Usaha Syariah (UUS), pada tabel Statistik Perbankan Syariah periode Januari 2010-Desember 2014 yang berjumlah 60 bulan sehingga sampel penelitian ini berjumlah $60(n=60)$.

\section{Prosedur Pengumpulan Data}


Erlangga, et al/Jurnal Ekonomi Syariah Teori dan Terapan Vol. 3 No. 7 Juli 2016: 561-574; PENGARUH TOTAL AKTIVA, CAPITAL ADEQUACY RATIO (CAR), FINANCE TO DEPOSIT RATIO (FDR) DAN NON PERFORMING FINANCING (NPF) TERHADAP RETURN ON ASSETS (ROA) BANK UMUM SYARIAH DI INDONESIA PERIODE 2010-2014

Data yang digunakan dalam penelitian ini adalah data sekunder bersifat kuantitatif, berupa rasio-rasio kevangan yang terbit setiap akhir periode yang diterbitkan melalui website resmi Otoritas Jasa Kevangan (OJK) dengan metode Dokumentasi. Prosedur pengumpulan data juga melalui studi pustaka yaitu mengkaji buku-buku, jurnal, skripsi dan lain-lain yang berkaitan dengan penelitian. Hal tersebut dilakukan untuk memperoleh landasan teori yang komprehensif (mudah dipahami).

\section{Teknik Analisis}

Teknik analisis yang digunakan dalam penelitian ini adalah regresi linier berganda dengan time series. Teknik analisis ini juga digunakan untuk memperoleh informasi dalam mengetahui pengaruh, ada atau tidaknya pengaruh Total Aktiva, CAR,FDR, dan NPF terhadap ROA pada bank syariah. Adapun alat analisis yang digunakan adalah analisis regresi linier berganda, dengan melakukan uji asumsi klasik terlebih dahulu.

\section{HASIL DAN PEMBAHASAN}

\section{Uji Asumsi Klasik}

\section{Uji Multikolinearitas}

Multikolinearitas merupakan situasi multi korelasi diantara variabel satu dengan variabel independen lainnya atau diantara variabel independenindependen tersebut. Data dibentuk hubungan satu antara variabel dengan variabel lain. Berikut di bawah ini merupakan tabel hasil uji multikolinearitas.
Tabel 2.

Hasil Uji Multikolinearitas

\begin{tabular}{|l|r|c|}
\hline \multirow{2}{*}{ Model } & \multicolumn{2}{|c|}{ Collinearity Statistics } \\
\cline { 2 - 3 } & Tolerance & VIF \\
\hline (Constant) & & \\
\hline Total Aktiva & .838 & 1.193 \\
\hline FDR & .760 & 1.316 \\
\hline CAR & .892 & 1.121 \\
\hline NPF & .966 & 1.036 \\
\hline
\end{tabular}

a. Dependent Variable: ROA

Sumber : Hasil Penelitian, diolah (2015)

Pada table diatas diketahui bahwa nilai VIF dari masing-masing variabel bernilai kurang dari 10 dan Nilai Tolerance dari masing-masing variabel lebih dari 0,1. Data-data tersebut dapat disimpulkan bahwa diantara variabel independen tidak terjadi multikolinearitas atau tidak ada multi korelasi pada model regresi linier.

\section{Uji Heteroskedatisitas}

Heteroskedatisitas merupakan situasi terjadi ketidaksamaan varians residual dari satu pengamatan ke pengamatan yang lain. Cara melihat heteroskedatisitas adalah melihat ada atau tidaknya pola tertentu pada Scatter Plot yang terdapat dalam output statistik. Jika tidak ada pola yang jelas dan titik menyebar diatas dan dibayah nol pada sumbu $Y$, maka tidak terjadi heteroskedatisistas (Sujarweni, 2014: 186). 
Erlangga, et al/Jurnal Ekonomi Syariah Teori dan Terapan Vol. 3 No. 7 Juli 2016: 561-574; PENGARUH TOTAL AKTIVA, CAPITAL ADEQUACY RATIO (CAR), FINANCE TO DEPOSIT RATIO (FDR) DAN NON PERFORMING FINANCING (NPF) TERHADAP RETURN ON ASSETS (ROA) BANK UMUM SYARIAH DI INDONESIA PERIODE 2010-2014

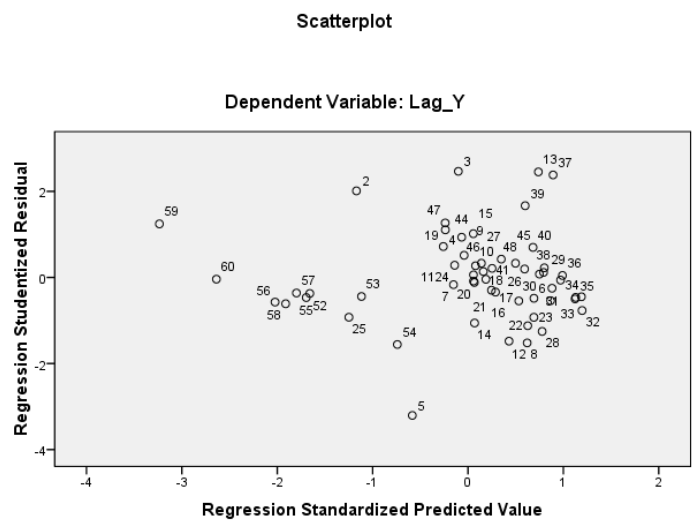

Sumber : Hasil Penelitian, diolah (2015)

Gambar 1.

Hasil Uji Heteroskedatisitas

Dari hasil uji heteroskedatisitas diatas, terlihat titik-titik menyebar secara acak, dan tidak membentuk suatu pola tertentu yang jelas. Titik-titik tersebut menyebar baik diatas maupun dibawah angka nol pada sumbu Y. Hal ini menunjukkan tidak terjadi heteroskedatisitas pada model regresi liner berganda ini.

\section{Uji Autokorelasi}

Autokorelasi merupakan situasi dimana adanya korelasi antara kesalahan pengganggu pada suatu periode ( $t$ ), dengan kesalahan pengganggu pada periode sebelumnya (t-1). Untuk mendeteksi ada atau tidaknya autokorelasi dengan melihat dari D-W (Durbin-Watson) pada tabel summary output statistik (Santoso, 2000:144).

\section{Tabel 3.}

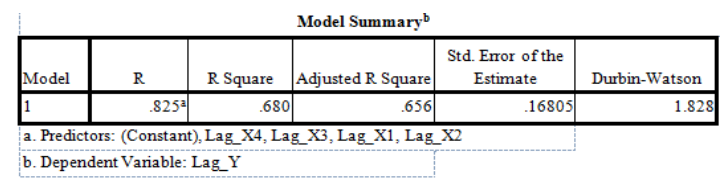

Hasil Uji Autokorelasi
Sumber: Hasil Penelitian, diolah (2015)

Pada tabel diatas terlihat bahwa nilai Durbin Watson pada hasil Regresi Linier berganda sebesar 1,828. Pada tabel Durbin Watson didapat nilai $\mathrm{dL}=1.42642$ dan $\mathrm{dU}=1,72526$ untuk sampel berjumlah 57 dan $k=5$. Maka dapat dihitung sebagai berikut :

Deteksi Autokorelasi Positif:

DW Hitung 1,828 > DU: 1,72526 maka tidak terdapat autokorelasi positif.

Deteksi Autokorelasi Negatif:

$(4-1,828)=2,061>$ DU: 1,72526 maka tidak terdapat autokorelasi negatif.

Maka dapat disimpulkan pada analisis regresi linier berganda dalam penelitian ini tidak terdapat autokorelasi positif dan negative atau sesuai dengan bebas autokorelasi bila DW > DU dan 4-DW > DU.

\section{Uji Normalitas}

Uji normalitas adalah untuk menentukan apakah variabel berdistribusi normal atau tidak. Uji normalitas bertujuan untuk mengetahui distribusi data dalam variabel yang akan digunakan dalam penelitian. Data yang baik dan layak digunakan dalam penelitian adalah data yang memiliki distribusi normal. Normalitas data dapat dilihat dengan menggunakan uji normal Kolmogorov-Smirnov (Sujarweni, 2014: 52). 
Erlangga, et al/Jurnal Ekonomi Syariah Teori dan Terapan Vol. 3 No. 7 Juli 2016: 561-574; PENGARUH TOTAL AKTIVA, CAPITAL ADEQUACY RATIO (CAR), FINANCE TO DEPOSIT RATIO (FDR) DAN NON PERFORMING FINANCING (NPF) TERHADAP RETURN ON ASSETS (ROA) BANK UMUM SYARIAH DI INDONESIA PERIODE 2010-2014

Tabel 4.

Hasil uji Normalitas

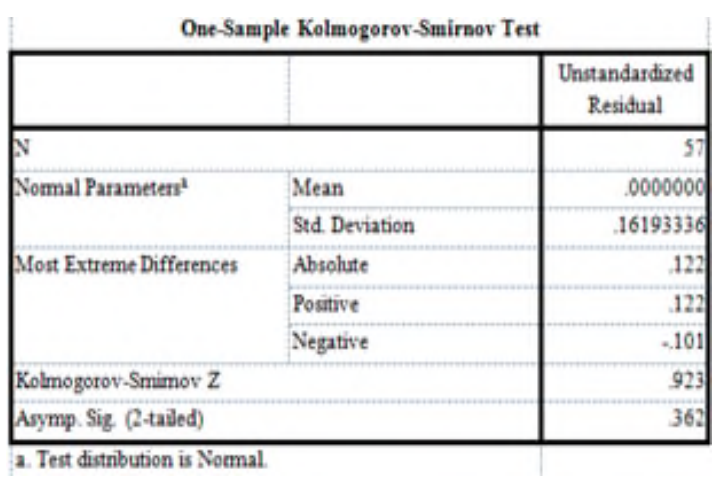

Sumber : Hasil Penelitian, diolah (2015)

Berdasarkan uji normalitas dengan Kolmogorov-Smirnov test diperoleh nilai Kolmogorov-smirnov Z sebesar 0,923 dan Asymp Sig. (2 tailed) sebesar 0,362 lebih besar dari 0,05. Dapat disimpulkan bahwa data tersebut berdistribusi normal.

\section{Analisis Regresi Linear Berganda}

Tabel 5.

Regresi Linear Berganda

\begin{tabular}{|c|c|c|c|}
\hline \multicolumn{2}{|c|}{ Model } & \multicolumn{2}{|c|}{$\begin{array}{l}\text { Unstandardized } \\
\text { Coefficients }\end{array}$} \\
\hline & & B & Std. Error \\
\hline \multirow[t]{5}{*}{1} & (Constant) & -.483 & 561 \\
\hline & Lag Xt & $-2.696 \mathrm{E}-6$ & .000 \\
\hline & $\operatorname{Lag} \times 2$ & 042 & .008 \\
\hline & $\operatorname{Lag} \times 3$ & 023 & 019 \\
\hline & Lag_X4 & .347 & .047 \\
\hline \multicolumn{3}{|c|}{ a. Dependent Vanable: Lag_Y } & \\
\hline
\end{tabular}

Sumber : Hasil Penelitian, diolah (2015)

Dari tabel diatas dapat dibentuk persamaan model analisis regresi linear berganda sebagai berikut:

$\operatorname{ROA}=(-0,483)-2,696 \times 10-6$ Total_Aktiva + 0,042 FDR $+0,023$ CAR $-0,347 \mathrm{NPF}$

\section{Koefisien Determinasi}

Tabel 6.

Hasil Koefisien Determinasi

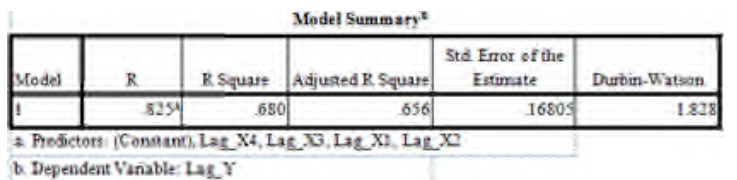

Sumber : Hasil Penelitian, diolah (2015)

Dari tabel koefisien determinasi di atas, dapat dilihat bahwa angka koefisien korelasi (R) sebesar 0,680. Hal ini berarti bahwa hubungan antar variabel independen dengan variabel dependen sebesar $68 \%$. Dari angka tersebut dapat diambil kesimpulan bahwa hubungan antara variabel independen dengan variabel dependen cukup kuat.

Besarnya R Square (R2) adalah 0,680. Hasil perhitungan statistik ini berarti bahwa kemampuan variabel independen dalam menerangkan variasi perubahan variabel dependen sebesar 68\%, sedangkan sisanya sebesar $\quad 32 \% \quad$ (100\%-68\%) diterangkan oleh faktor-faktor lain di luar model regresi yang dianalisis dalam penelitian ini.

\section{Pengujian Hipotesis}

\section{Uji F (Secara Simultan)}

Uji F digunakan untuk menguji apakah variabel bebas secara simultan atau bersama-sama berpengaruh signifikan terhadap variabel terikat.

Berikut hasil Uji $F$ (secara simultan) dalam penelitian ini yang menggunakan SPSS Statistic version 20 yang ditunjukkan dalam tabel dibawah ini. 
Erlangga, et al/Jurnal Ekonomi Syariah Teori dan Terapan Vol. 3 No. 7 Juli 2016: 561-574; PENGARUH TOTAL AKTIVA, CAPITAL ADEQUACY RATIO (CAR), FINANCE TO DEPOSIT RATIO (FDR) DAN NON PERFORMING FINANCING (NPF) TERHADAP RETURN ON ASSETS (ROA) BANK UMUM SYARIAH DI INDONESIA PERIODE 2010-2014

Tabel 7.

Hasil Uji F

\begin{tabular}{|c|c|c|c|c|c|}
\hline \multicolumn{6}{|c|}{ ANOVA $A^{b}$} \\
\hline Model & Sum of Squares & $d f$ & Mean Square & $\mathrm{F}$ & Sig. \\
\hline Regression & 3.124 & 4 & .781 & 27.655 & .000 \\
\hline Residual & 1.468 & 52 & .028 & & \\
\hline Total & 4.592 & 56 & & & \\
\hline
\end{tabular}

a. Predictors: (Constant), Lag X4, Lag X3, Lag X1, Lag_ X2

b. Dependent Variable: Lag_Y

Sumber : Hasil Penelitian, diolah (2015)

Dari tabel hasil uji $F$ diatas, terlihat bahwa F hitung adalah sebesar 27,655. Sedangkan $F$ tabel dapat dihitung dengan cara :

Numerator $(d f 1=k-1) \rightarrow 5-1=4$

Denumerator $(d f 2=n-k) \rightarrow 57-5=52$

Derajat kebebasan (a) $=0,05$

Maka nilai $F$ tabel $=2,55$

Dari hasil uji F diketahui bahwa F hitung adalah sebesar 27,655 > 2,55 (F Tabel), maka $\mathrm{Hl}$ diterima dan $\mathrm{HO}$ ditolak. Hasil Uji $\mathrm{F}$ juga menunjukan bahwa semua angka signifikan, karena tingkat probabilitas sig 0,000 . Nilai $0,000<0,05$. Dengan demikian, secara statistik bahwa Ukuran Perusahaan (Total Aktiva), Likuiditas (FDR), Kecukupan Modal (CAR) dan Pembiayaan Bermasalah (NPF) secara bersama-sama atau secara simultan berpengaruh signifikan terhadap profitabilitas (ROA) pada Bank Syariah di Indonesia periode Januari 2010-Desember 2014.

\section{Uji † (Secara Parsial)}

Uji † (Secara Parsial) digunakan untuk mengetahui hubungan masing-masing variabel independen (Total Aktiva, FDR, CAR, NPF) terhadap variabel dependen (ROA) secara Individual atau secara parsial
Hasil Uji † (secara parsial) dalam penelitian ini dengan menggunakan SPSS Statistics version 20 yang ditunjukkan dalam tabel sebagai berikut.

Tabel 8.

Hasil Uji $†$

Coefficients $^{\mathbf{a}}$

\begin{tabular}{|c|c|c|c|c|c|c|}
\hline \multirow{2}{*}{\multicolumn{2}{|c|}{ Model }} & \multicolumn{2}{|c|}{$\begin{array}{l}\text { Unstandardized } \\
\text { Coefficients }\end{array}$} & \multirow{2}{*}{\begin{tabular}{c|}
$\begin{array}{c}\text { Standardized } \\
\text { Coefficients }\end{array}$ \\
Beta \\
\end{tabular}} & \multirow[b]{2}{*}{ T } & \multirow[b]{2}{*}{ Sig. } \\
\hline & & B & Std. Error & & & \\
\hline \multirow[t]{5}{*}{1} & (Constant) & -.483 & .561 & & -.862 & .393 \\
\hline & Lag_X1 & $-2.696 \mathrm{E}-6$ & .000 & -.571 & -6.664 & .000 \\
\hline & Lag_X2 & .042 & .008 & .473 & 5.255 & .000 \\
\hline & Lag_X3 & .023 & .019 & .103 & 1.238 & .221 \\
\hline & Lag_X4 & -.347 & .047 & -.590 & -7.393 & .000 \\
\hline
\end{tabular}

Sumber : Hasil Penelitian, diolah (2015)

Dari tabel diatas, maka dapat disimpulkan sebagai berikut.

\section{a. Pengaruh Total Aktiva terhadap ROA}

Nilai † hitung untuk variabel Total Aktiva sebesar $-6,664$ hal ini menunjukan Total Aktiva berpengaruh negatif terhadap ROA. Nilai probabilitas (sig. penelitian) untuk variabel Total Aktiva $(0,000)<0,05$, maka $\mathrm{H} 1$ diterima dan Ho ditolak.

Dapat disimpulkan bahwa secara statistik Ukuran Perusahaan (Total Aktiva) secara parsial berpengaruh negatif dan signifikan terhadap tingkat profitabilitas (ROA) pada Bank Syariah di Indonesia periode Januari 2010-Desember 2014.

\section{b. Pengaruh FDR terhadap ROA}

Nilai † hitung untuk variabel FDR sebesar 5,255 hal ini menunjukkan FDR berpengaruh positif terhadap ROA. Nilai probabilitas (sig. penelitian) untuk 
Erlangga, et al/Jurnal Ekonomi Syariah Teori dan Terapan Vol. 3 No. 7 Juli 2016: 561-574; PENGARUH TOTAL AKTIVA, CAPITAL ADEQUACY RATIO (CAR), FINANCE TO DEPOSIT RATIO (FDR) DAN NON PERFORMING FINANCING (NPF) TERHADAP RETURN ON ASSETS (ROA) BANK UMUM SYARIAH DI INDONESIA PERIODE 2010-2014

variabel $\operatorname{FDR}(0,000)<0,05$, maka $\mathrm{H} 1$ diterima dan Ho ditolak.

Dapat disimpulkan bahwa secara statistik Likuiditas (FDR) secara parsial berpengaruh positif dan signifikan terhadap tingkat profitabilitas (ROA) pada Bank Syariah di Indonesia periode Januari 2010-Desember 2014.

\section{c. Pengaruh CAR terhadap ROA}

Nilai $†$ hitung untuk variabel CAR sebesar 1,238 hal ini menunjukkan FDR berpengaruh positif terhadap ROA. Nilai probabilitas (sig. penelitian) untuk variabel $\operatorname{FDR}(0,221)>0,05$, maka $\mathrm{Hl}$ ditolak dan Ho diterima.

Dapat disimpulkan bahwa secara statistik Kecukupan Modal (CAR) secara parsial berpengaruh positif dan tidak signifikan terhadap tingkat profitabilitas (ROA) pada Bank Syariah di Indonesia periode Januari 2010Desember 2014.

\section{d. Pengaruh NPF terhadap ROA}

Nilai † hitung untuk variabel NPF sebesar -7,393 hal ini menunjukkan NPF berpengaruh negatif terhadap ROA. Nilai probabilitas (sig. penelitian) untuk variabel NPF $(0,000)<0,05$, maka $\mathrm{Hl}$ diterima dan Ho ditolak.

Dapat disimpulkan bahwa secara statistik Pembiayaan Bermasalah (NPF) secara parsial berpengaruh negatif dan signifikan terhadap tingkat profitabilitas (ROA) pada Bank Syariah di Indonesia periode Januari 2010Desember 2014.

\section{Pembahasan}

\section{Pengaruh (Total Aktiva) Terhadap ROA}

Berdasarkan analisis data dan pengujian hipotesis yang telah dilakukan dalam penelitian ini, dapat diketahui bahwa ukuran perusahaan terbukti berpengaruh negatif dan signifikan terhadap ROA. Hasil penelitian ini mendukung penelitian yang dilakukan oleh Kosmidou (2008), dimana disebutkan bahwa ukuran perusahaan berpengaruh negatif dan signifikan terhadap profitabilitas bank karena bank yang lebih besar belum tentu dapat bekerja secara lebih efisien dibandingkan dengan bank dengan ukuran lebih kecil. Semakin besar total aktiva suatu perusahaan memang akan membuat semakin besar peluang perusahaan tersebut dalam menghasilkan laba namun jika diikuti kemampuan perusahaan tersebut dalam mengelola asetnya.

\section{Pengaruh FDR terhadap ROA}

Menurut analisis data dan pengujian hipotesis yang telah dilakukan, hasil yang diperoleh adalah adanya hubungan yang positif signifikan antara likuiditas dengan Profitabilitas yang diproksikan dengan ROA. Pengaruh likuiditas yang berhubungan positif signifikan dengan ROA juga ditemukan dalam penelitian milik Werdaningtyas (2002)dalam Sartika (2012). Hasil regresi ditemukan bahwa likuiditas yang diproksi dengan Loan to Deposit Ratio (LDR), menunjukkan seberapa 
Erlangga, et al/Jurnal Ekonomi Syariah Teori dan Terapan Vol. 3 No. 7 Juli 2016: 561-574; PENGARUH TOTAL AKTIVA, CAPITAL ADEQUACY RATIO (CAR), FINANCE TO DEPOSIT RATIO (FDR) DAN NON PERFORMING FINANCING (NPF) TERHADAP RETURN ON ASSETS (ROA) BANK UMUM SYARIAH DI INDONESIA PERIODE 2010-2014

besar dana bank dilepas untuk pembiayaan berpengaruh negatif terhadap profitabilitas. Semakin Besar nilai rasio likuiditas maka semakin tidak likuid bank tersebut yang tentunya kan berpengaruh terhadap penurunan Profitabilitas.

\section{Pengaruh CAR terhadap ROA}

Berdasarkan analisis data yang telah dilakukan dapat diketahui bahwa variabel kecukupan modal yang diproksikan dengan Capital Adequacy Ratio(CAR) berpengaruh positif dan tidak signifikan terhadap ROA. Hasil penelitian ini bertolak belakang dengan penelitian milik Sartika (2012) yang menyatakan bahwa CAR berpengaruh negatif namun didukung penelitian milik Fahmy (2013) yang hasil penelitiannya menyatakan CAR tidak berpengaruh signifikan terhadap ROA.

Capital Adequacy Ratio (CAR) merupakan rasio kecukupan modal yang menunjukkan kemampuan bank dalam mempertahankan dan mencukupi manajemen bank dalam mengidentifikasi, mengukur, mengawasi, dan mengontrol risikorisiko yang timbul, dan dapat berpengaruh terhadap besarnya modal bank.

Hasil penelitian ini mengindikasikan bahwa besar kecilnya Capital Adequacy Ratio (CAR) menyebabkan besar kecilnya keuntungan atau profitabilitas bank namun tidak terlalu signifikan perubahnnya. Bank yang memiliki modal besar, namun tidak dapat menggunakan modalnya itu secara efektif untuk menghasilkan laba, maka modal yang besar tersebut tidak memberikan keuntungan yang berarti bagi Bank Syariah. Hal ini disebabkan bank lebih mengandalkan pinjaman sebagai sumber pendapatan dan tidak menggunakan seluruh potensi modalnya untuk meningkatkan profitabilitas. Hal tersebut menyebabkan CAR tidak menjadi faktor yang berpengaruh secara signifikan terhadap profitabilitas bank.

\section{Pengaruh NPF terhadap ROA}

Hasil penelitian ini sesuai dengan hasil penelitian yang dilakukan oleh Nugroho (2011) yang hasil penelitiannya menunjukkan NPF berpengaruh negatif dan signifikan terhadap ROA. Pembiayaan bermasalah atau Non Performing Loan (NPL) pada bank konvensional dan Non Performing Financing pada bank syariah, merupakan risiko yang terkandung dalam setiap pemberian pembiayaan atau kredit oleh bank kepada nasabah. Risiko tersebut berupa keadaan dimana pembiayaan atau kredit tidak dapat kembali tepat pada waktunya.

Non Performing Financing (NPF) mempunyai hubungan negatif terhadap Return On Assets (ROA), sehingga hasil penelitian ini 
Erlangga, et al/Jurnal Ekonomi Syariah Teori dan Terapan Vol. 3 No. 7 Juli 2016: 561-574; PENGARUH TOTAL AKTIVA, CAPITAL ADEQUACY RATIO (CAR), FINANCE TO DEPOSIT RATIO (FDR) DAN NON PERFORMING FINANCING (NPF) TERHADAP RETURN ON ASSETS (ROA) BANK UMUM SYARIAH DI INDONESIA PERIODE 2010-2014

menunjukkan bahwa semakin besar NPF maka akan mengakibatkan semakin menurunnya ROA, yang berarti kinerja keuangan bank yang menurun karena risiko kredit atau pembiayaan bermasalah semakin besar. Begitu pula sebaliknya, apabila NPF turun maka ROA akan semakin meningkat, yang berarti kinerja keuangan bank semakin membaik.

\section{SIMPULAN}

Berdasarkan hasil analisa dan pembahasan pada bab sebelumnya, maka penelitian ini dapat diambil kesimpulan sebagai berikut.

a) Berdasarkan hasil Uji F statistik (secara simultan) dengan signifikansi $a=0,05$, maka dapat disimpulkan bahwa Ukuran Perusahaan (Total Aktiva), Likuiditas (FDR), Kecukupan Modal (CAR), Pembiayaan Bermasalah (NPF) secara bersama-sama atau Simultan berpengaruh signifikan terhadap Profitabilitas (ROA) pada Bank Syariah di Indonesia periode Januari 2010-Desember 2014.

b) Berdasarkan hasil Uji $†$ statistik (secara parsial) dengan signifikansi $a=0,05$, maka dapat disimpulkan bahwa Ukuran Perusahaan (Total Aktiva), Likuiditas (FDR), Pembiayaan Bermasalah (NPF) secara parsial berpengaruh signifikan terhadap Profitabilitas (ROA) pada Bank Syariah di Indonesia periode Januari 2010-
Desember 2014. Sedangkan Kecukupan Modal (CAR) tidak berpengaruh secara signifikan signifikan terhadap Profitabilitas (ROA) pada Bank Syariah di Indonesia periode Januari 2010Desember 2014.

\section{DAFTAR PUSTAKA}

Al-Qurán

Antonio, Muhammad Syafií. 2001, Bank Syariah dari Teori Ke Praktek. Jakarta: Gema Insani.

Chiang, Alpha C. 2009. Dasar-Dasar Matematika Ekonomi jilid 1. Jakarta: Erlangga

Dendawijaya, Lukman. 2009. Manajemen Perbankan. Bogor: Ghalia Indonesia.

Fahmy, M Shalahuddin. 2013. Pengaruh CAR,NPF, BOPO, dan FDR Terhadap Profitabilitas Bank Umum Syariah. Skripsi Program Sarjana Universitas Islam Sunan Kalijaga Yogyakarta (Dipublikasikan) Hasibuan, Malayu SP. 2005. Dasar-Dasar Perbankan. Jakarta: Bumi Akasara.

Muhammad. 2005. Manajemen Dana Bank Syariah. Jakarta: PT Raja Grafindo Persada.

Nugroho, Aluisius Wishnu. 2011. Analisis Pengaruh FDR, NPF, BOPO, KAP, dan PLO Terhadap Return on Asset (Studi kasus pada Bank Syariah periode tahun 2006-2010). Undip E-Journal System Portal.

Santoso, Singgih. 2000. Latihan SPSS Statistik Parametrik. Jakarta: PT Elex Media Komputindo. 
Erlangga, et al/Jurnal Ekonomi Syariah Teori dan Terapan Vol. 3 No. 7 Juli 2016: 561-574; PENGARUH TOTAL AKTIVA, CAPITAL ADEQUACY RATIO (CAR), FINANCE TO DEPOSIT RATIO (FDR) DAN NON PERFORMING FINANCING (NPF) TERHADAP RETURN ON ASSETS (ROA) BANK UMUM SYARIAH DI INDONESIA PERIODE 2010-2014

Sartika, Dewi. 2012. Analisis Pengaruh Ukuran Perusahaan, Kecukupan Modal, Kualitas Aktiva Produktif, dan Likuiditas Terhadap ROA (Studi Kasus pada bank syariah di indonesia periode 2006-2010). Skripsi Program Sarjana Universitas Hasanuddin (Dipublikasikan)

Sugiyono. 2004. Metodologi Penelitian. Bandung: Alfabetis.

Sujarweni, V. Wiratna. 2014. SPSS Untuk Penelitian. Yogyakarta: Pustaka Baru Press.

Tondowidjojo, Fenny dan Anna Purwaningsih. 2007. "Manfaat Perubahan Rasio Keuangan Dalam Memprediksi Perubahan Laba: Studi Empiris Pada Perusahaan Perbankan Yang Terdaftar Di Bursa Efek Jakarta". Modus, Vol. 19, No. 2, Hal:144-156

Wuryatiningsih. 2002. Bank dan Lembaga Kevangan lainnya, Jakarta :Salemba Empat.

Website :

http://www.bi.go.id/id/statistik/perbankan /syariah/Default (diakses pada Maret 20 